\title{
Synchronized reproductive success of the main bivalve species in the Wadden Sea: causes and consequences
}

\author{
J. J. Beukema ${ }^{1, *}$, R. Dekker ${ }^{1}$, K. Essink ${ }^{2}$, H. Michaelis ${ }^{3}$ \\ ${ }^{1}$ Netherlands Institute for Sea Research, PO Box 59, 1790 AB Den Burg, The Netherlands \\ ${ }^{2}$ National Institute for Coastal Marine Management/RIKZ, PO Box 207, 9750 AE, Haren, The Netherlands \\ ${ }^{3}$ Niedersächsisches Landesamt für Ökologie, Forschungsstelle Küste, An der Mühle 5, 26548, Norderney, Germany
}

\begin{abstract}
This paper surveys data obtained during 3 decades (1969-1999) of monitoring the macrobenthic fauna of a $50 \mathrm{~km}^{2}$ tidal-flat area in the Wadden Sea (Balgzand) and compares the annual figures with similar long-term data series from other parts of the Wadden Sea (Groningen, Norderney). Despite enormous year-to-year variability in annual recruitment of particularly the bivalves, totalbiomass values were remarkably stable. Detailed data are presented on the annual variability in recruitment success of the 4 most important bivalve species of the Balgzand area (Cerastoderma edule, Macoma balthica, Mya arenaria, and Mytilus edulis). Together these 4 species usually accounted for more than half of the total zoobenthic biomass and largely governed its year-to-year fluctuations. Recruit numbers of the 4 species observed in 27 summers showed similar relationships with the character of the foregoing winter. Such relationships were also observed in other Wadden Sea areas in The Netherlands and Germany. These common relationships resulted in a certain synchrony of recruitment success between the species (within areas) and between areas (within species). Thus, over vast areas (hundreds of $\mathrm{km}$ ), bivalve recruit densities were generally (though not invariably) high after severe winters and low after mild winters. The resulting strong year-to-year variability in recruit numbers (with standard errors exceeding long-term means) was only just passed on to subsequent total-biomass values for the following 3 reasons: (1) the biomass of any species was generally composed of more than 1 year class, (2) the various species did not reach their maximal biomass at the same age (time elapsed after recruitment), and (3) feedback mechanisms (enhanced reduction of numbers at high abundance) were effective in some species.
\end{abstract}

KEY WORDS: Recruitment $\cdot$ Biomass $\cdot$ Zoobenthos $\cdot$ Winter character $\cdot$ Cerastoderma $\cdot$ Macoma Mya $\cdot$ Mytilus

Resale or republication not permitted without written consent of the publisher

\section{INTRODUCTION}

In natural ecosystems, numbers and biomass of animals change with time. As an estuarine area at a rather high latitude, the Wadden Sea is among the less stable ecosystems (Wolff 1973). Though regulatory forces are at work in the Wadden Sea, both of the bottom-up type (food limitation: Jensen 1993, Kamermans 1993, Beu-

\footnotetext{
*E-mail: janb@nioz.nl
}

kema \& Cadée 1997) and the top-down type (predation: Reise 1985, Beukema et al. 2000), there remains a lot of unpredictable variability caused particularly by weather conditions. Bivalves, in particular, are notorious for their large year-to-year variability in recruitment; the size of failing and successful cohorts may differ by orders of magnitude at that stage (Beukema 1982, Möller \& Rosenberg 1983, Möller 1986, Desprez et al. 1991, Ducrotoy et al. 1991). Four bivalve species are among the top 5 species contributing to the total biomass of the bottom fauna of the tidal flats of the 
western Wadden Sea (Beukema 1976), viz. Mya arenaria L., Mytilus edulis L., Cerastoderma edule (L.) and Macoma balthica (L.). Two main questions are dealt with in the present paper: (1) Are the fluctuations in annual recruitment of these bivalves in some way related (synchronized)? and (2) To what extent is the strong recruitment variability passed on to changes in benthic biomass and thus to the food supply of mollusk-eating predators such as flatfish and birds (oystercatchers, eiders)?

Synchronization by climatic factors appears to occur in a wide variety of species and environments (Hudson \& Cattadori 1999). In coastal areas around the North Sea, winter-temperature-induced cases of synchrony in distant populations have also been observed in several species of mollusks and worms (Beukema et al. 1996) and in plaice (Fox et al. 2000). Frequent recruitment failure after mild winters and highly successful recruitment after severe winters has been observed in several species of coastal marine bivalves, including the above 4 species (Beukema 1982, 1992b, Beukema et al. 1998 and references therein). Such similar relationships between winter character and recruitment in different species will not only tend to synchronize recruitment success of these 4 important species, but will also lead to some synchronization of recruit abundance at distant places, as winters in any year are of a similar character over vast areas, from France to Finland in western Europe (Beukema et al. 1996). Examples of bivalve-recruitment synchrony at different sampling stations can be found for Macoma balthica in Desprez et al. (1991) and in Beukema et al. (1996), for Cerastoderma edule in Ducrotoy et al. (1991), for Scrobicularia plana da Costa in Essink et al. (1991), and for Angulus fabula Meuschen in Ziegelmeier (1978). A striking example of synchrony of recruitment of 2 different species (mussel and cockle) can be found in Fig. 11 of Beukema et al. (1993).

Numerical density at recruitment appears to be the main factor determining future biomass and production of a bivalve cohort (Möller \& Rosenberg 1983, Coosen et al. 1994, Beukema \& Cadée 1999, Van der Meer et al. 2001). Therefore, it is expected that the enormous year-to-year fluctuations in annual recruitment will be passed on to biomass variability. This might have serious consequences for their predators. If several important species experience low recruitment simultaneously over vast areas, the total benthic fauna might become scarce in certain years. This will particularly be so if recruitment fails during a number of years in close succession. In such years, the main food of mollusk-eating predators might be in short supply. Contrary to this general expectation, results of longterm biomass assessments in Wadden Sea areas (though characterized by heavily fluctuating recruit- ment) usually reveal rather stable values of total zoobenthic biomass (Dörjes et al. 1986, Beukema 1989b, Beukema \& Cadeé 1997, Essink et al. 1998).

In the present paper, long-term data series are presented to show how strong the synchronization of recruitment was in different bivalve species that are important contributors to total benthic biomass. Both within-species comparisons of density fluctuations in distant areas will be considered as well as betweenspecies comparisons within restricted areas. Furthermore, factors will be discussed that subsequently contribute to a dampening of the variability initiated by recruitment, such as the multi-cohort composition of total biomass in most species, between-species differences in the time elapsing before maximal cohort biomass is reached, and feedback mechanisms (e.g. negatively density-dependent survival after recruitment).

Results from a sampling program of zoobenthos running since the early 1970 s on the Balgzand tidal flats provided most of the data. Additional long-term data series were available from similar long-term sampling programs executed in other Wadden Sea areas, between 100 and $200 \mathrm{~km}$ east of Balgzand.

\section{METHODS}

The Balgzand long-term monitoring program of the benthic macrofauna started around 1970 and is still running. It comprises bi-annual estimates of numbers and biomass of all macrobenthic (those retained on $1 \mathrm{~mm}$ sieves) species at 15 stations scattered over the $50 \mathrm{~km}^{2}$ tidal flat area called Balgzand and includes all intertidal levels and nearly all sediment types. Balgzand is situated in the westernmost part of the Wadden Sea (at $52^{\circ} 54^{\prime} \mathrm{N}, 4^{\circ} 48^{\prime} \mathrm{E}$ ). Details of sampling methods, position and other characteristics of the sampling stations, including their faunal composition, can be found in Beukema (1988).

Annual numbers of 0-group bivalves were assessed in late summer (mostly August) in a consistent way since 1973. Samples taken in the period 1969-1972 differed in sampling area or month. Therefore, only the 27 yr series 1973-1999 is homogeneous. The biomass data used were collected in late winter (mostly in March) and a homogeneous data series exists from 1970. For an evaluation of biomass changes, we prefer late-winter values because this biomass data series is longer than the summer one; larger samples were taken at that time rather than in summer and most species reach their annual minimal value in late winter (Beukema 1974) and therefore these values will be most critical for the food supply of their predators.

As far as possible, all bivalves encountered in the samples were allotted to year classes (born in the same 
year) by reading the number of year marks on their shells. Such age reading can satisfactorily be done in Cerastoderma edule (compare Beukema 1989a) and in Macoma balthica (see Lammens 1967), but we trusted our readings only up to an age of 2 or 3 yr in Mytilus edulis, whereas for the time being we abandoned age reading completely in Mya arenaria.

All Balgzand values shown are averages from samples taken at 15 stations and are expressed either in numbers $\mathrm{m}^{-2}$ (numerical densities) or in $\mathrm{g}$ AFDW (ashfree dry weight) $\mathrm{m}^{-2}$ (biomass).

To compare fluctuations in recruit numbers on Balgzand with those in other areas, data were used from 3 other long-term sampling programs in the Wadden Sea. Arranged from west to east these areas are:

(1) 'Subtidal': 3 transects of $1500 \mathrm{~m}$ each in the western part of the Dutch Wadden Sea (20 to $50 \mathrm{~km}$ northeast of Balgzand) at a depth of 2 to $6 \mathrm{~m}$ below meantide level. Samples were taken in August/September of the 1989-1999 period. Further details can be found in Dekker \& De Bruin (1999).

(2) 'Groningen': at the Groninger Wad $\left(53^{\circ} 27^{\prime} \mathrm{N}\right.$, $6^{\circ} 32^{\prime} \mathrm{E}$ ), about $130 \mathrm{~km}$ east of the Balgzand, samples taken at 5 square stations (16 to 20 per station, together 0.15 to $0.48 \mathrm{~m}^{2}$ per station) within a $5 \mathrm{~km}^{2}$ area in July to September for $24 \mathrm{yr}$ (the 1976-1999 period) were used. This small area covers only a restricted range of intertidal levels (immersion time 35 to $55 \%$ ) and sediment types ( 5 to $15 \%$ silt). Further details can be found in Essink (1978). The 'subtidal' and 'Groningen' samplings are part of the biological monitoring program of the Ministry of Transport, Public Works and Water Management.

(3) 'Norderney': at the tidal flats south of the EastFriesian island of Norderney $\left(53^{\circ} 42^{\prime} \mathrm{N}, 7^{\circ} 15^{\prime} \mathrm{E}\right.$, about $170 \mathrm{~km}$ east of the Balgzand) samples were taken at 4 stations along a $1 \mathrm{~km}$ transect perpendicular to the coast for 24 yr (1976-1999). These 4 stations cover a restricted range of intertidal levels (immersion time about 35 to $55 \%$ ) and sediment types (<5\% silt). Further details can be found in Dörjes et al. (1986).

Data on winter temperatures (January to March) were taken from monthly weather reports from the KNMI weather station De Kooy at only $1 \mathrm{~km}$ from Balgzand. Though winter temperatures in more eastern parts of the Wadden Sea are generally slightly lower, they are strongly correlated all over the Wadden Sea and thus they rank in the same order.

The year-to-year variation of the mean values presented below was ex- pressed in the coefficient of variation, i.e. 100 times the standard deviation divided by the mean. High coefficients (in the order of 100) indicate strong betweenyear variability of the underlying annual data. The relationships between data series were expressed as Spearman's rank correlation coefficient r. High (negative or) positive values of $\mathrm{r}$ (above about 0.5 ) indicate strong (anti)synchronization of data series.

\section{RESULTS}

\section{Annual recruitment on Balgzand tidal flats}

During the 27 yr period of regular observations, the numerical densities of 0-group (spat) bivalves of the 4 species varied by 2 or 3 orders of magnitude in Cerastoderma edule (Fig. 1a), Mya arenaria (Fig. 1b) and Mytilus edulis (Fig. 1c), but only about 30-fold in Macoma balthica (Fig. 1d). Already at first sight, some synchrony between the 4 species is apparent, e.g. the common peaks in 1979 and 1987 and the common dips in 1974, 1988, 1989, 1990, 1993, 1995, 1998, and 1999. Summers with peak numbers of spat were often preceded by severe winters (e.g. 1979 and 1987), whereas recruitment failures frequently occurred after extremely mild winters (e.g. 1989, 1990, and 1998), compare Fig. 1a-d with Fig. 1f. In all 4 species, relationships between 0-group densities on Balgzand and temperatures of the immediately foregoing winter (half a year earlier) were significantly negative (first column of Table 1). Correlations with temperatures in earlier winters (i.e. longer time lags) proved to be weak and non-significant.

The similar (negative) relationships found in the above-mentioned bivalve species between summer recruitment and the immediately preceding winter

Table 1. Spearman's rank correlation coefficients of relationships between air temperatures in the foregoing winter and subsequent 0-group densities in 4 bivalve species in various parts of the Wadden Sea: 3 intertidal areas (Balgzand, Groningen, and Norderney) and 1 subtidal area. Levels of statistical significance of correlation coefficients are: ${ }^{*} \mathrm{p}<0.05,{ }^{* *} \mathrm{p}<0.01$, or ${ }^{* * *} \mathrm{p}<0.001$

\begin{tabular}{|lcccc|}
\hline & Balgzand & Groningen & Norderney & Subtidal \\
\hline No. of years & 27 & 24 & 24 & 11 \\
No. of stations & 15 & 5 & 4 & 3 \\
Area sampled $\left(\mathrm{m}^{2}\right)$ & 6.3 & $0.8-2.4$ & 0.7 & 2.7 \\
Macoma balthica & $-0.67^{* * *}$ & $-0.49^{*}$ & $-0.52^{*}$ & -0.18 \\
Cerastoderma edule & $-0.51^{* *}$ & -0.20 & $-0.50^{*}$ & -0.50 \\
Mytilus edulis & $-0.48^{*}$ & & & -0.22 \\
Mya arenaria & $-0.46^{*}$ & $-0.50^{*}$ & & $-0.66^{*}$ \\
All species & $-0.59^{* *}$ & $-0.46^{*}$ & & $-0.64^{*}$ \\
\hline
\end{tabular}


temperature must lead to some synchronization of spat fall success of these species. Pair-wise Spearman's rank correlation tests of annual spat densities yielded several highly significant correlation coefficients, notably between Cerastoderma edule, Mya arenaria and Mytilus edulis (Table 2). Though lower, the 3 coefficients between Macoma balthica spat numbers and those of the other 3 species were also statistically significant. Thus, recruit numbers of the 4 species did not fluctuate independently. High values in certain species coincided more frequently with high than with low values in other species. As a consequence, total numbers of bivalve spat also showed large fluctuations (Fig. 1e). Total spat numbers of the 4 species together varied from 71 (in 1993) to 2281 (in 1979), with a long-term (27 yr) average of $595 \mathrm{~m}^{-2}$. The standard deviation of this mean amounted to 549 and the coefficient of variation to $92 \%$. This coefficient is lower than the high values observed in the 0 -groups of the 4 separate species (first column of Table 3 ).
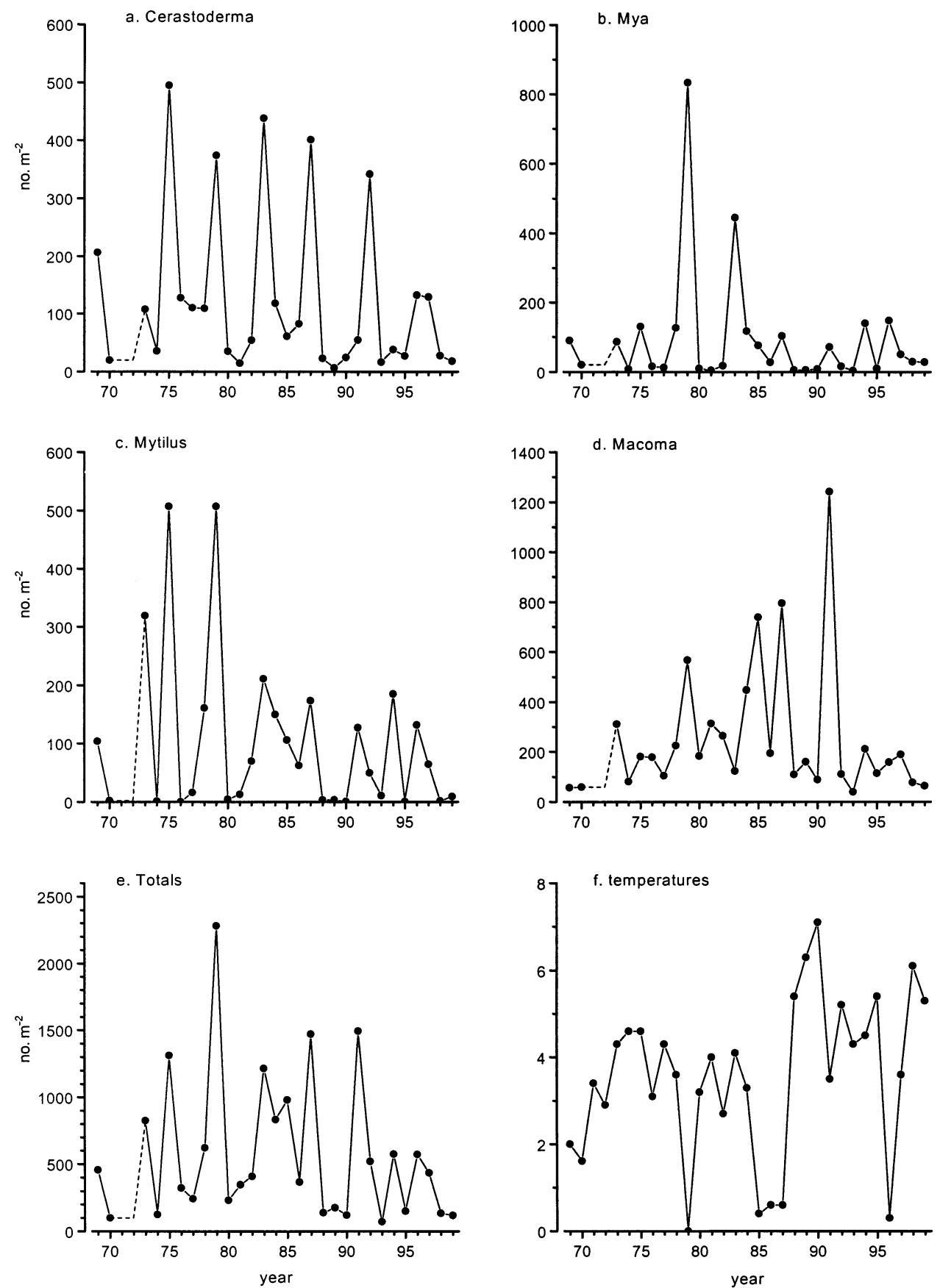

Fig. 1. Long-term data series on the annual abundance (no. $\mathrm{m}^{-2}$ ) of 0-group individuals observed in August for 29 yr (1969-1970, 1973-1999) at Balgzand (averages of 15 fixed sampling stations) in 4 bivalve species and their totals: (a) Cerastoderma edule, (b) Mya arenaria, (c) Mytilus edulis, (d) Macoma balthica, (e) sums of these 4 species. Estimates for the years 1969 and 1970 are less precise and were not used in the various calculations; estimates for August 1971 and 1972 are far from complete, but from sampling in other months it is known that recruit densities must have been low in these 2 yr (see also Fig. 1 of Beukema 1982, showing the means of the imperfect data sets of these years). (f) Mean air temperatures in the 3 mo periods January to March 19691999 at a nearby weather station 
The frequency distribution of the total spat numbers was far from a normal one (Fig. 2). Relatively few observations were close to the long-term average, whereas no less than 10 out of the total of 27 observations showed a value of $<40 \%$ of the average and 5 were $>200 \%$ of the mean. Thus, there were more extreme than close-to-average values. More than half of the years can be characterized as either clear failures or outstanding successes.

There was no auto-correlation within the time series of recruitment data (as concluded also by Van der Meer et al. 2001 from a more sophisticated analysis). At first sight, years with successful and failing recruitment alternated in more or less random order. At closer inspection, 4 yr distances between maximal values appear to be relatively frequent (particularly in Fig. 1a,c,e). In particular during the late 1970s, the 1980s and the early 1990s, spat numbers appeared to peak regularly at $4 \mathrm{yr}$ intervals (the maximal values in 1975, 1979, 1983, 1987, and 1991). However, the data included in Fig. 1 also show that such rhythm was absent both before 1975 (there were certainly no peaks in or around 1971, compare Fig. 1 of Beukema 1982) as well as after 1991 (no peaks in 1995 or 1999). Thus, if the entire data series is considered, there is no consistency in the 'cycles'.

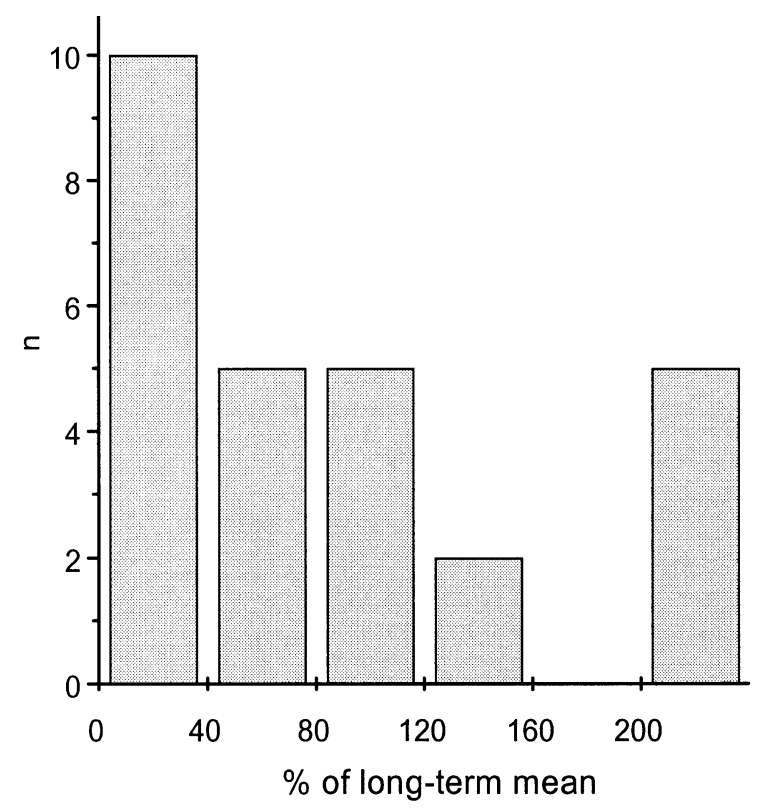

Fig. 2. Frequency distribution of 27 annual (1973-1999) observations (vertical axis) of sums of spat numbers of 4 species (see Fig. 1e), expressed as a percentage of the long-term mean $\left(100 \%=595 \mathrm{~m}^{-2}\right)$

\section{Annual recruitment in other Wadden Sea areas}

As on Balgzand, 0-group densities observed in late summer in other Wadden Sea areas were also negatively correlated with temperatures from the preceding winter (Table 1). In most cases, the absolute values of the correlation coefficients were smaller than on Balgzand. The substantially smaller areas sampled annually in these areas may explain this.

These similar relationships (observed in all 4 bivalve species) of spat numbers with winter temperatures will generate parallel fluctuations of abundance of these species in distant areas. In 3 species, long-term fluctuations in spat numbers could be compared between the 3 tidal-flat areas which are 100 to $200 \mathrm{~km}$ apart (such a comparison was not possible in Mytilus edulis, as this species was rarely found in the samples taken in Groningen and Norderney; comparisons with the short subtidal series were not considered meaningful). In Macoma balthica as well as in Cerastoderma edule and Mya arenaria, significantly positive correlation coefficients were found between recruit densities at Balgzand, Groningen, and Norderney (Table 4). These

Table 3. Coefficients of variation (100× standard deviation/ mean) and (within brackets) mean number $\mathrm{m}^{-2}$ or mean $\mathrm{g} \mathrm{m}^{-2}$ for 27 yr (1973-1999) data series of each of 4 species of bivalves (Mya arenaria, Mytilus edulis, Cerastoderma edule and Macoma balthica) and these 4 species together as observed on Balgzand (annual means of 15 sampling stations), viz. 0-group numbers $\mathrm{m}^{-2}$ in August, 1-group numbers per $\mathrm{m}^{-2}$ in August (no data available for $M y a$ ), and biomass of all age groups together $\left(\mathrm{g}\right.$ AFDW $\left.\mathrm{m}^{-2}\right)$ in late winter

\begin{tabular}{|lrcc|}
\hline & 0-group & 1-group & Biomass \\
\hline M. arenaria & $185(93)$ & & $56(7.5)$ \\
$M$. edulis & $133(107)$ & $135(7)$ & $92(2.1)$ \\
$C$. edule & $115(126)$ & $152(23)$ & $97(4.7)$ \\
$M$. balthica & $102(269)$ & $66(38)$ & $42(2.9)$ \\
4 bivalve species & $92(595)$ & & $37(17.3)$ \\
Total zoobenthos & & & $32(28.2)$ \\
\hline
\end{tabular}


relationships were highly significant only in $M$. balthica, the species whose recruitment generally showed the strongest relationship with temperatures from the preceding winter (compare Table 1). In M. edulis, there is also evidence that the recruitment fluctuations observed at Balgzand reflect spat fall success at least within the Dutch Wadden Sea (J. de Vlas pers. comm.: Balgzand 0-group densities were significantly correlated with fishermen's reports on the size of seed-mussel stocks all over the Dutch Wadden Sea).

\section{Biomass variability on Balgzand}

During the 27 yr period 1973-1999, the total macrozoobenthic late-winter biomass ranged from 14 to $44 \mathrm{~g}$ $\mathrm{m}^{-2}$ (Fig. 3), with an average of $28.2 \mathrm{~g} \mathrm{~m}^{-2}$ and a relatively low coefficient of variation of $32 \%$ (Table 3 ). Fluctuations in total zoobenthic biomass clearly reflected variability in total-bivalve biomass. The coefficient of variation for the sum of biomass values of the 4 important bivalve species (viz. $37 \%$ ) hardly exceeded that of total biomass.

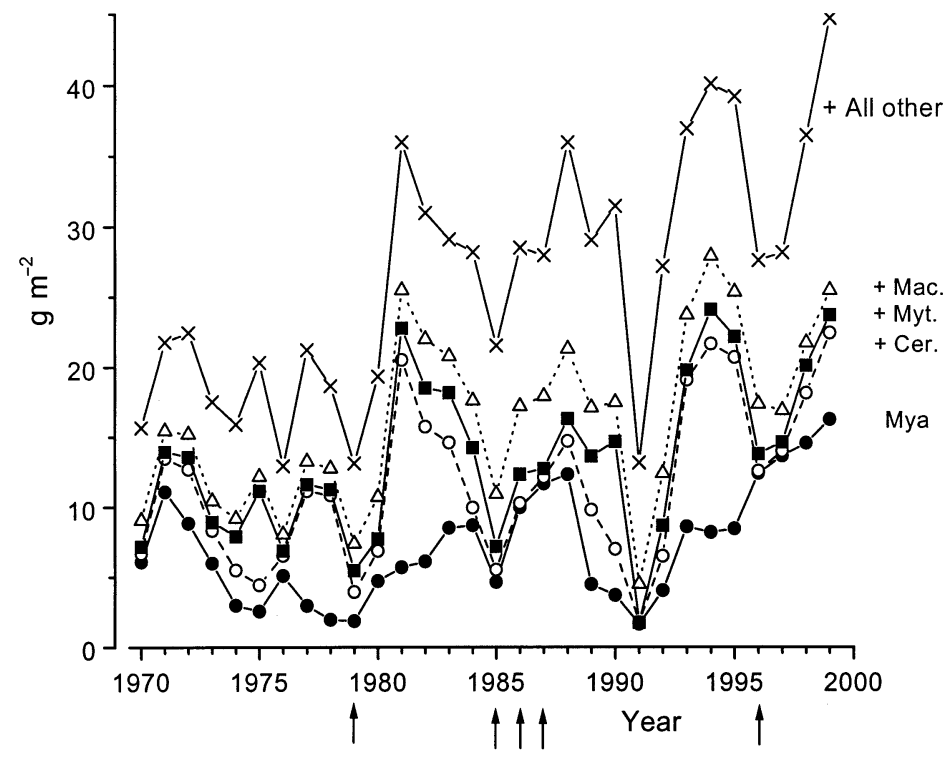

Fig. 3. Long-term (1970-1999) changes of biomass values (g ash-free dry weight $\mathrm{m}^{-2}$ ) of 4 bivalve species (Mya arenaria, Cerastoderma edule, Mytilus edulis, and Macoma balthica) and of all macrozoobenthic species at Balgzand (means of 15 fixed sampling stations sampled in late winter, at the annual minimum of biomass). Note that all lines (except the lower one, for $M$. arenaria) show summations of biomass values of more than 1 species (the spaces between the lines indicate the biomass values of the individual bivalve species). (•) Mya, (o) Mya + Cerastoderma, (ロ) Mya + Cerastoderma + Mytilus, (४) Mya + Cerastoderma + Mytilus + Macoma, (×) Mya + all others. Severe winters (compare Fig. 1f) indicated by arrows on the horizontal axis
Table 4. Spearman's rank correlation coefficients of numerical densities in 3 bivalve species observed in the same years ( $\mathrm{n}=24$ : 1976-1999) at different tidal flats of the Wadden Sea. Statistical significance indicated as in Table 1 (Spearman test used 1 -sided in the present case because only positive values were expected)

\begin{tabular}{|lcc|}
\hline & Balgzand & Groningen \\
\hline $\begin{array}{l}\text { Macoma balthica } \\
\text { Groningen }\end{array}$ & $+0.42^{*}$ & \\
Norderney & $+0.61^{* *}$ & $+0.57^{* *}$ \\
Cerastoderma edule & & \\
Groningen & $+0.39^{*}$ & $+0.37^{*}$ \\
Norderney & +0.33 & \\
Mya arenaria & & \\
Groningen & $+0.40^{*}$ & \\
\hline
\end{tabular}

Together, the 4 important bivalve species accounted for more than half of the total biomass in all but $2 \mathrm{yr}$, viz. 1991 and 1992 (Fig. 3). The 27 yr means in the 4 species amounted to 7.5 (Mya arenaria), 4.7 (Cerastoderma edule), 2.9 (Macoma balthica), and 2.1 (Mytilus edulis) $\mathrm{g} \mathrm{m}^{-2}$, with a 4 -species total of $17.3 \mathrm{~g} \mathrm{~m}^{-2}$. Their coefficients of variation, ranging from 42 to $97 \%$ in the separate species, were lower than those for recruit densities in all species, particularly so in $M$. balthica and $M$. arenaria (compare last with first column of Table 3).

The greatest influences on variability in total biomass originated from Mya arenaria (largest individual contribution to total biomass) and Cerastoderma edule (largest coefficient of variation combined with substantial contribution to total biomass). Annual biomass values of these 2 species were significantly positively correlated with total zoobenthic biomass ( $M$. arenaria: $\mathrm{r}=0.63, \mathrm{n}=27, \mathrm{p}<0.01$; Cerastoderma edule: $\mathrm{r}=0.59$, $\mathrm{n}=27, \mathrm{p}<0.01$ ). Year-to-year changes in total-biomass values (upper line in Fig. 3) roughly followed those of the sum of biomass of these 2 species (lower broken line of Fig. 3). The sums of the biomass values of the 4 bivalve species almost completely explained the between-year variation in total zoobenthic biomass $\left(\mathrm{r}^{2}=0.93\right)$.

Total zoobenthic biomass was generally lower after cold than after mild winters $(r=0.43, n=27, p<0.05)$. This was due to several cold-sensitive species, including Cerastoderma edule $(\mathrm{r}=0.52, \mathrm{p}<0.01)$.

\section{Age composition of bivalve stocks}

Age structure of biomass differed between the species. The cockle Cerastoderma edule and mussel Mytilus edulis had a high share of young animals, 
0 -group specimens frequently exceeding $50 \%$ of their total biomass, whereas this proportion rarely exceeded $10 \%$ in Macoma balthica and Mya arenaria (unpubl. results from the Balgzand data set). Mean annual survival in the adult stage was relatively low in cockles and mussels, amounting on average to about $33 \%$ in adult C. edule (see Beukema \& Cadée 1999) and to about $30 \%$ in adult $M$. edulis (J.J.B. unpubl. obs.). In the other 2 species, mean annual survival of adults was higher (about $60 \%$ in $M$. balthica, see Beukema 1980 and Van der Meer et al. 2001; no precise estimate is available in $M$. arenaria, because of difficulties in reading year marks on their shells; the present informed guess stems from decline rates of numerical densities in peaking year classes). As a consequence, a large proportion of biomass in M. balthica and M. arenaria was present at any time as heavy and old individuals belonging to several year classes. In contrast, longevity was low in $M$. edulis and $C$. edule (cockles $>6$ yr old being rare, see Beukema 1989a) and their biomass was generally made up of only a few year classes, as also observed in the cockle in other tidal-flat areas by Ducrotoy et al. (1991).

Cockle and mussel cohorts reached their maximal biomass generally by the end of their second growing season, at an age of slightly over 1 yr. In Macoma balthica this happened 1 or 2 yr later, with (on average) similarly high biomass values at the end of the third or fourth growing season. Due to problems with age determination, such age cannot precisely be stated for Mya arenaria, but in view of the dominance of old and heavy individuals in their biomass, age at maximal cohort biomass may be even higher in $M$. arenaria than in M. balthica. By observation of marked clams, Brousseau (1978) confirms that annual survival rates are exceptionally high in adult $M$. arenaria.

\section{Feedback mechanisms}

Negative feedback processes can reduce variability in bivalve abundance by, e.g., enhancement of recruitment success at low adult abundance or by reduction of survival at high densities of adults and/or recruits.

In 3 species (Macoma balthica, Mya arenaria, and Mytilus edulis), the relationships between the sizes (biomass) of the adult stocks and numerical densities of their recruits were weak, with correlation coefficients ranging from 0.0 to only 0.2 ( $\mathrm{n}=27$, unpubl. results from the Balgzand data set). However, in Cerastoderma edule this coefficient amounted to -0.54 ( $\mathrm{p}<$ 0.01 , Spearman rank test with $n=27$ ). Thus only in the cockle is evidence available that dense adult stocks suppressed their own recruitment. In the other 3 species, numbers of recruits found in August were not consistently higher or lower at low than at high adult densities and were thus (on average) independent of egg numbers spawned by the local population a few months earlier.

As total zoobenthic biomass was relatively low after cold winters (see above), a negative relationship of recruit numbers with total zoobenthos is expected from their negative correlations with winter temperatures. This correlation between recruitment success and total biomass was indeed negative in all 4 species, significantly so in Cerastoderma edule ( $\mathrm{r}=-0.55, \mathrm{p}<0.01$ ) and in Macoma balthica $(\mathrm{r}=-0.40, \mathrm{p}<0.05)$, whereas it amounted to -0.33 and -0.29 in Mytilus edulis and Mya arenaria, respectively.

Evidence for improved survival of settled recruits at low recruit densities was observed in Macoma balthica. Only this species showed a substantial decline with age of the coefficient of variation of density estimates (compare first and second column of Table 3). Year-to-year variability in abundance decreased during the year following recruitment, suggesting that survival was lower in strong than in weak year classes. On average, $14 \%$ of the $M$. balthica recruits were still present on Balgzand 1 yr after recruitment. However, this proportion was invariably lower (ranging from 7 to $11 \%$ ) in the $7 \mathrm{yr}$ (out of 26) with highest densities at recruitment (Fig. 4). Such negatively density-dependent differences in first-year survival were not observed in the Balgzand populations of the other important bivalve species.

\section{DISCUSSION}

\section{Causes of synchronized recruitment variability}

Exceptionally successful recruitment in bivalve populations after cold winters has been observed in several intertidal areas and in several species (see references in Beukema et al. 1998). It is not clear what exactly causes recruitment to be particularly successful after the coldest winters. The following possible mechanisms can be suggested to explain why recruitment is generally higher after cold than after mild preceeding winters:

(1) High adult weights and condition (by lower weight loss at lower winter temperatures, see Zwarts 1991, Honkoop \& Beukema 1997) at spawning, resulting in high egg numbers or big eggs after cold winters (Honkoop \& Van der Meer 1997). Though higher egg numbers were indeed observed in Macoma balthica in the Wadden Sea after cold rather than mild winters, higher egg numbers did not result in significantly enhanced recruitment as only a minor part of recruitment variation could be explained by variation in 


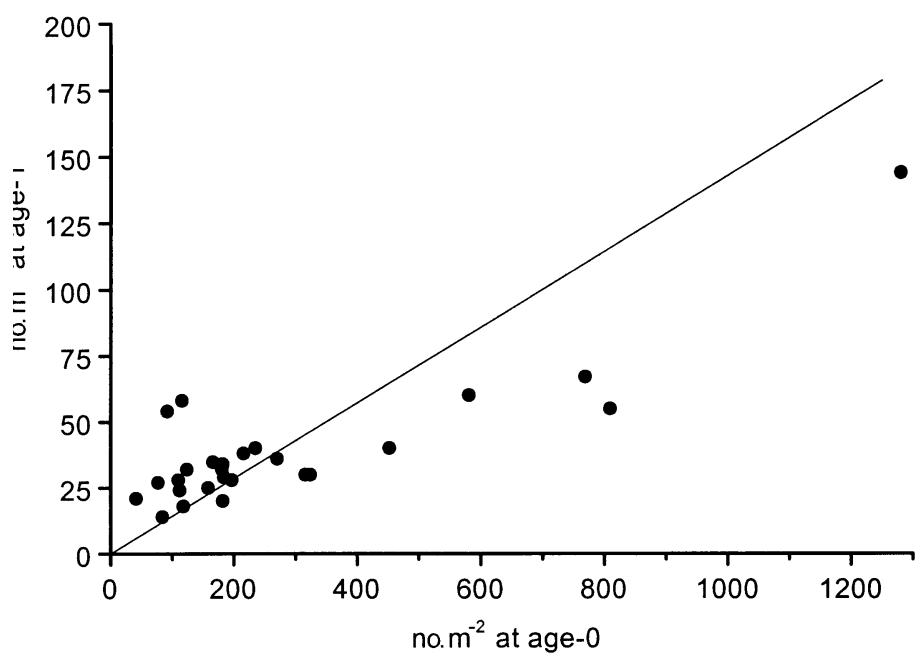

Fig. 4. Relationship between numerical densities (no. $\mathrm{m}^{-2}$, means of samples taken in August at 15 sampling stations on Balgzand) of 0-group Macoma balthica born in the 26 successive summers 1973-1998 and numerical densities of the same cohorts 1 yr later. The line represents the relationship at a constant survival of $14 \%$ (i.e. the mean survival)

numbers of eggs spawned $\mathrm{m}^{-2}$ (Honkoop et al. 1998). Therefore, this is not a likely explanation.

(2) Low abundance of predators in spring periods after cold winters enhance survival of early life stages. Though successful completion of the risky pelagic larval stage may play a key role (Thorson 1950), very little is actually known about the role of predation in such early life stages of bivalves. More is known on the fate of post-settlement stages, and processes at this life stage will also play a significant role in the regulation of their numbers (Ólafsson et al. 1994). One of the factors specifically playing a differential role after cold and mild winters is the timing of predators. On the Wadden Sea tidal flats, shore crabs and shrimps appear later in the spring after cold than after mild winters (Beukema 1991b, 1992a). The late arrival of decapod predators after a cold winter (in this case 1979) was also noted in coastal areas in western Sweden (Pihl \& Rosenberg 1982) and was followed by highly successful recruitment in some bivalves, particularly in Mya arenaria (Möller 1986). In several bivalve species, recruit densities are higher in areas protected from epibenthic predators by predator-exclusion cages than in surrounding unprotected areas (Reise 1985, Fernandes et al. 1999, Richards et al. 1999). Predation by shore crabs appears to play a significant role in the survival of cockle spat on tidal flats of the Danish Wadden Sea, where recruitment in all 4 important bivalve species was very successful in a year following a severe winter (Jensen \& Jensen 1985). In Macoma balthica numbers of recruits per $\mathrm{m}^{2}$ and numbers of recruits per
1000 spawned eggs were substantially higher at low than at high shrimp Crangon crangon densities (Beukema et al. 1998). Thus, there appears to be not only sufficient evidence for a key role of predation on settled postlarvae in the determination of recruitment success of bivalves on tidal flats, but also for a differential role after cold and mild winters.

(3) High mortality in cold-sensitive species in cold winters reduces the abundance of various species and total biomass on tidal flats after severe winters (Beukema 1979, 1992b). This will result in more space and less competition and disturbance. Among the high-biomass species, Cerastoderma edule in particular is sensitive to low winter temperatures and was invariably scarce on the Wadden Sea tidal flats after severe winters (Beukema 1979, 1985). At high densities, adult cockles exert significant adverse effects on juveniles of many species by mechanical disturbance (Flach 1996). They also inhale larvae of various species, including their own (André et al. 1993). Thus the invariably low cockle densities on Wadden Sea tidal flats after cold winters may contribute to high recruitment in bivalves in the subsequent summer by reduction of mortality in both the larval stage (less inhalement) and in the benthic postlarvae (less sediment disturbance) as compared to years with larger cockle stocks.

From the observed correlative relationships between recruitment success and winter-character-dependent abundances of specific species (in particular Cerastoderma edule) or all species together (total biomass), it cannot be decided which species actually inhibited recruitment in the 4 bivalves. However, in $C$. edule 2 activities are actually known to contribute to such a process.

In conclusion: at least 2 possible ways (viz. predation and disturbance, and possibly also competition) are known by which winter character can (indirectly) affect recruitment success.

Other climatic factors than winter temperatures may as well affect settlement of bivalve larvae or survival of settled postlarvae and thus synchronize annual recruitment success over vast areas. For example, high rainfall caused poor spat settlement on nearly all mussel beds in the Exe estuary and the frequency of gales determined the further course of the numbers of settled spat in a way that was similar on various beds (McGrorty \& Goss-Custard 1993). In the Wash, UK, the settlement of cockles (and to a lesser extent of mussels) was favoured by the frequent occurrence of easterly winds in late spring and early summer (Young et al. 1996). Other examples are populations of species near the northern (cold) edge of their area of distribution. They all tend to show simultaneous declines in numbers in cold winters and high recruitment and/or 
growth in warm summers (Menesguen \& Dreves 1987 and references therein, Dekker \& Beukema 1993, 1999).

\section{Consequences of winter-induced recruitment variability: biomass synchronization}

If winter character (or any other climatic factor that fluctuates similarly over vast geographic areas) is a major determinant of recruit densities in several species, one of the consequences is the occurrence of synchronization of recruitment success between species (because these species show basically the same relationship with the weather factor) and also between distant populations of the same species (because winters show the same character over vast areas). Parallel fluctuations of recruit densities in several species can be seen in Fig. 1 and the degree of synchrony is quantified in Table 2.

Parallel fluctuations between distant populations were found in all 3 species in which data were available from different sampling areas (Table 4). These areas were found to be up to $170 \mathrm{~km}$ apart, the longest distance between 2 sampling areas. There is some evidence that the synchronized patterns of bivalve recruitment cover the entire Wadden Sea, e.g. the exceptionally strong year classes born in 1979 of many species extended to the tidal flats of SchleswigHolstein (Reise 1987), Germany, at a distance of about $400 \mathrm{~km}$ from Balgzand. Several examples of synchronized fluctuation patterns of distant (tens or hundreds of $\mathrm{km}$ ) populations of various marine benthic species are listed in Beukema et al. (1996). Synchrony in time series of abundance (the so-called Moran effect) appears to occur quite commonly and in a wide variety of species and environments (Hudson \& Cattadori 1999).

Thus, over vast areas population size can vary in similar patterns with simultaneously occurring maximal and minimal values. Such simultaneous peaks and dips are not limited to 1 species but may apply to several species, as in the bivalve species dealt with in the present paper. Such extensive synchrony of abundance patterns may have substantial consequences for ecosystem functioning if it includes fluctuations in biomass and production.

The 4 bivalve species dealt with in this study do not only account for a substantial part (usually $>50 \%$ ) of the total tidal-flat zoobenthic biomass, they also govern to a large extent the year-to-year fluctuations of total biomass (Fig. 3). Thus, the fate of the populations of only a few bivalve species explained most of the longterm (1970-1999) course of total biomass. Relatively low biomass values (e.g. 1979, 1985, and 1996) prevailed immediately after severe winters (compare Fig. 3 with Fig. 1f), when in the Wadden Sea Cerastoderma edule populations died out almost completely. Recovery of biomass after such events always proceeded rapidly. The usually larger-than-average bivalve-recruit densities in summers after cold winters (Table 1, Fig. 1) contributed to these quick recoveries, sometimes resulting in high biomass peaks (e.g. the 1981 total-biomass peak was caused by the high abundance of adult cockles that were born in 1979, see Fig. 3).

Usually, summers with successful recruitment occurred frequently enough to prevent any substantial and rapid decline of total biomass as a consequence of prolonged periods of recruitment failure. However, the low total biomass observed in early 1991, caused by an abnormally low proportion of bivalves (Fig. 3), can be ascribed largely to failing recruitment in all important bivalve species during 3 yr in succession (1988, 1989, and 1990, see Fig. 1a-e). This 3 yr period was characterized by mild winters (Fig. 1f) and (according to seawater temperatures in the main tidal inlet of the western Wadden Sea) early 1989 and 1990 were even the warmest winters of the century (Van der Hoeven 1982 and more recent daily observations by NIOZ, Texel, courtesy H. van Aken pers. comm.). The consequences of recruitment failure in these $3 \mathrm{yr}$ were aggravated by unrestricted fishery for cockles and mussels in the summer of 1990, when nearly all cockle banks and virtually all mussel beds were removed from the tidal flats of the Dutch Wadden Sea (Beukema \& Cadée 1996, Smit et al. 1998). Due to the switching of bivalve-eating birds to remaining prey types, survival of Macoma balthica and Mya arenaria in 1990-1991 was also lower than normal (Beukema 1993). For these reasons, more than half of the decline of bivalve biomass from $18 \mathrm{~g} \mathrm{~m}^{-2}$ in early 1990 to $5 \mathrm{~g} \mathrm{~m}^{-2}$ in early 1991 (Beukema \& Cadée 1996) can be attributed to manmade effects. Minimum estimates of direct losses to fisheries amounted to about $8 \mathrm{~g} \mathrm{~m}^{-2}$ of mussels plus an unknown amount of cockles and those of indirect losses due to predators shifting to alternative prey amounted to about $1 \mathrm{~g} \mathrm{~m}^{-2}$ (data from Beukema 1993). Had the fishery on Balgzand been closed before 1990, the 1991 biomass value would have been rather low, but certainly not the lowest of the 1970-1999 period.

\section{Consequences of recruitment variability: biomass variability}

It is clear from the above that year-to-year variability in recruitment success of bivalve species has substantial influence on the course of zoobenthic biomass on the Wadden Sea tidal flats. However, the variability in recruit numbers was an order of magnitude higher than that of the resulting biomass (compare Fig. 3 with 
Fig. 1e; Table 3). During an 8 yr study of Mytilus edulis beds in the Exe estuary, McGrorty et al. (1990) found annual variation to be an order of magnitude smaller in adult numbers than in densities of settling larvae. In all species (or species groups) studied on Balgzand, coefficients of variation were invariably higher in 0-group numbers than in biomass (Table 3). Thus, the high variability in recruitment was not fully passed on to biomass. At least the following processes appear to be involved in dampening biomass variability:

(1) Abundance estimates at recruitment refer to single cohorts, whereas biomass values of bivalve species are generally composed of several year classes. This is particularly the case in long-lived species such as Mya arenaria and Macoma balthica, but also biomass of Cerastoderma edule and Mytilus edulis is usually made up of more than 1 year class. Thus in all the above species, animals born in a certain year contributed to biomass during periods of $>1 \mathrm{yr}$. Such multiple composition of biomass is bound to reduce coefficients of variation and this effect should be particularly strong in the long-lived $M$. arenaria and $M$. balthica. This was indeed the case: reductions were substantial in $M$. arenaria (70\%, compare Table 3: from 185 to 56) and $M$. balthica (59\%) but much less so in M. edulis (31\%) and C. edule $(16 \%)$.

(2) The maximal contribution of a single cohort to its lifetime biomass is reached at different ages in different bivalve species, viz. 1 or 2 yr after recruitment in short-lived and rapidly growing species, but several years after the year of birth in long-lived species with initially low growth rates. Thus, even if large cohorts of different species arise in the same year, their contributions to biomass peak in different years. In this way, small contributions of some species in any year were frequently compensated by large contributions of other species. An example can be seen in Fig. 3: the slow increase of Mya arenaria biomass during no less than 5 yr after 1979 (a year with a highly successful recruitment in several species) as opposed to the rapid wax and wane of Cerastoderma edule biomass in the same period.

(3) Phenomena showing negative density dependence.

(3.1) All species showed a negative density dependence of survival in their earliest pre-recruitment life stages, producing on average fewer recruits per adult at high adult densities than at low adult stocks (see 'Results: Feedback mechanisms'). This negative relationship was especially obvious in Cerastoderma edule, and was also observed in the Burry Inlet (Hancock 1973), in the Wash (Dare \& Walker 1992, cited by Young et al. 1996), on a local and temporal scale at the Swedish west coast (André \& Rosenberg 1991), and in 2 bays on the French Atlantic coast (Bachelet et al. 1992). Adults inhaling larvae of their own species (André et al.
1993) may accomplish it. This feedback mechanism does not really result in a low year-to-year variability at recruitment (it is not lower in $C$. edule than in the other species, see Table 3), but it will prevent a succession of years with highly successful recruitment. It may have contributed to the pseudo-regular alternation of $3 \mathrm{yr}$ with bad and 1 yr of good recruitment as observed in particular in C. edule in the late 1970s and in the 1980s (Fig. 1a).

In the other 3 species studied, no significant relationships between the size of the adult stocks and recruit abundance were found on Balgzand. However, such relationships might occur in other areas. Bonsdorff et al. (1986) found that adult Macoma balthica significantly reduced the survival rate of their own spat. Results of experiments by Möller (1986) indicate a negative influence of adult Mya arenaria on densities of settled spat of various bivalve species, including congeners. Williams (1980) and Peterson (1982) reported similar negative adult-juvenile interactions in bivalves. Ólafsson (1989) observed growth reduction of juvenile M. balthica by the presence of adult congeners.

(3.2) A lower survival after recruitment in large than in small cohorts, as observed in Macoma balthica (see Fig. 4), effectively reduces variability (Table 3: the coefficient of variation declined from 102 in recruits to 66 in $1 \mathrm{yr}$ olds in this species). Such negative density-dependent survival was already working in $M$. balthica populations in an earlier period of their benthic life, between June and August of their first year of life (Beukema 1982). A similar decline of first-year survival with increasing recruit densities was observed in Mytilus edulis in the Exe estuary by McGrorty et al. (1990).

On Balgzand, the other species showed no evidence of density-dependent survival after recruitment. In Cerastoderma edule the coefficient of variation even increased (Table 3), probably as a consequence of its extremely variable annual survival (as already noted by Franklin \& Pickett 1979).

(3.3) Lower growth rates in large than in small cohorts have been observed in Cerastoderma edule in the Dutch Wadden Sea by Kristensen (1957) and also in the Danish Wadden Sea by Jensen $(1992,1993)$. Such growth reduction in dense stocks of bivalves may be a general phenomenon (Peterson \& Black 1987) and will prevent extremely high biomass values when strong year classes grow up.

\section{Projection}

There is thus ample evidence that several processes contribute to an effective reduction of biomass variability. Only a rather small part of the large year-toyear variability in recruitment is passed to biomass 
fluctuations (Table 3). For this reason total biomass is rarely reduced to such low values that the food supply for birds on Wadden Sea tidal flats is endangered. During the $30 \mathrm{yr}$ period of observations on Balgzand, this occurred only once (in early 1991), and that was largely due to the fishery for mussels and cockles, which was at that time still unrestricted. Nowadays, substantial parts of the Wadden Sea are closed areas for such fisheries. Nevertheless, the envisaged risk for food shortage may not be as low as once per $30 \mathrm{yr}$. Recently, there has been growing conviction that the climate is becoming warmer and cold winters might become a rare phenomenon in the Wadden Sea area. Periods characterized by a succession of very mild winters might then become longer and as a consequence stocks of particularly short-lived bivalves such as cockles and mussels might more frequently decline to very low levels. The food supply for specialized bivalve-eating bird species (such as oystercatchers and eider ducks) and stocks of commercially important species (mussels and cockles) will possibly become less sure in the near future. By the very nature of the causation of recruitment fluctuations in Wadden Sea bivalves, this will be the case in several species at a time and, moreover, extend over vast areas.

Acknowledgements. We are grateful to Wim de Bruin for preparation of the figures. This is Publication No. 3565 of NIOZ, Texel.

\section{LITERATURE CITED}

André C, Rosenberg R (1991) Adult-larval interactions in the suspension-feeding bivalves Cerastoderma edule and Mya arenaria. Mar Ecol Prog Ser 71:227-234

André C, Jonsson PR, Lindegarth M (1993) Predation on settling bivalve larvae by benthic suspension feeders: the role of hydrodynamics and larval behaviour. Mar Ecol Prog Ser 97:183-192

Bachelet G, Guillou J, Labourg PJ (1992) Adult-larval and juvenile interactions in the suspension-feeding bivalve, Cerastoderma edule (L.): field observations and experiments. In: Colombo G, Ferrari I, Ceccherelli VU, Rossi R (eds) Marine eutrophication and population dynamics. Olsen \& Olsen, Fredensborg, p 175-182

Beukema JJ (1974) Seasonal changes in the biomass of the macro-benthos of a tidal flat area in the Dutch Wadden Sea. Neth J Sea Res 8:94-107

Beukema JJ (1976) Biomass and species richness of the macrobenthic animals living on the tidal flats of the Dutch Wadden Sea. Neth J Sea Res 10:236-261

Beukema JJ (1979) Biomass and species richness of the macrobenthic animals living on a tidal flat area in the Dutch Wadden Sea: effects of a severe winter. Neth J Sea Res 13: 203-223

Beukema JJ (1980) Calcimass and carbonate production by molluscs on the tidal flats in the Dutch Wadden Sea: I. The tellinid bivalve Macoma balthica. Neth J Sea Res 14: 323-338

Beukema JJ (1982) Annual variation in reproductive success and biomass of the major macrozoobenthic species living in a tidal flat area of the Wadden Sea. Neth J Sea Res 16: $37-45$

Beukema JJ (1985) Zoobenthos survival during severe winters on high and low tidal flats in the Dutch Wadden Sea. In: Gray JS, Christiansen ME (eds) Marine biology of polar regions and effects of stress on marine organisms. John Wiley, Chichester, p 351-361

Beukema JJ (1988) An evaluation of the ABC-method (abundance/biomass comparison) as applied to macrozoobenthic communities living on tidal flats in the Dutch Wadden Sea. Mar Biol 99:425-433

Beukema JJ (1989a) Bias in estimates of maximum life span, with an example of the edible cockle, Cerastoderma edule. Neth J Zool 39:79-85

Beukema JJ (1989b) Long-term changes in macrozoobenthic abundance on the tidal flats of the western part of the Dutch Wadden Sea. Helgol Meeresunters 43:405-415

Beukema JJ (1991) The abundance of shore crabs Carcinus maenas (L.) on a tidal flat in the Wadden Sea after cold and mild winters. J Exp Mar Biol Ecol 153:97-113

Beukema JJ (1992a) Dynamics of juvenile shrimp Crangon crangon in a tidal-flat nursery of the Wadden Sea after mild and cold winters. Mar Ecol Prog Ser 83:157-165

Beukema JJ (1992b) Expected changes in the Wadden Sea benthos in a warmer world: lessons from periods with mild winters. Neth J Sea Res 30:73-79

Beukema JJ (1993) Increased mortality in alternative bivalve prey during a period when the tidal flats of the Dutch Wadden Sea were devoid of mussels. Neth J Sea Res 31: 395-406

Beukema JJ, Cadée GC (1996) Consequences of the sudden removal of nearly all mussels and cockles from the Dutch Wadden Sea. PSZN I: Mar Ecol 17:279-289

Beukema JJ, Cadée GC (1997) Local differences in macrozoobenthic response to enhanced food supply caused by mild eutrophication in a Wadden Sea area: food is only locally a limiting factor. Limnol Oceanogr 42:1424-1435

Beukema JJ, Cadée GC (1999) An estimate of the sustainable rate of shell extraction from the Dutch Wadden Sea. J Appl Ecol 36:49-58

Beukema JJ, Essink K, Michaelis H, Zwarts L (1993) Year-toyear variability in the biomass of macrozoobenthic animals on tidal flats of the Wadden Sea: how predictable is this food source for birds? Neth J Sea Res 31:319-330

Beukema JJ, Essink K, Michaelis H (1996) The geographic scale of synchronized fluctuation patterns in zoobenthos populations as a key to underlying factors: climatic or man-induced. ICES J Mar Sci 53:964-971

Beukema JJ, Honkoop PJC, Dekker R (1998) Recruitment in Macoma balthica after mild and cold winters and its possible control by egg production and shrimp predation. Hydrobiologia 375/376:23-34

Beukema JJ, Essink K, Dekker R (2000) Long-term observations on the dynamics of three species of polychaetes living on tidal flats of the Wadden Sea: the role of weather and predator-prey interactions. J Anim Ecol 69:31-44

Bonsdorff E, Mattila J, Rönn C, Österman CS (1986) Multidimensional interactions in shallow soft-bottom ecosystems; testing the competitive exclusion principle. Ophelia Suppl 4:37-44

Brousseau DJ (1978) Population dynamics of the soft-shell clam Mya arenaria. Mar Biol 50:63-71

Coosen J, Twisk F, Van der Tol MWM, Lambeck RHD, Van Stralen MR, Meire PM (1994) Variability in stock assessment of cockles (Cerastoderma edule L.) in the Oosterschelde (in 1980-1990), in relation to environmental factors. Hydrobiologia 282/283:381-395 
Dekker R, Beukema JJ (1993) Dynamics and growth of a bivalve, Abra tenuis, at the northern edge of its distribution. J Mar Biol Assoc UK 73:497-511

Dekker R, Beukema JJ (1999) Relations of summer and winter temperatures with dynamics and growth of two bivalves, Tellina tenuis and Abra tenuis, on the northern edge of their intertidal distribution. J Sea Res 42:207-220

Dekker R, De Bruin W (1999) Het macrozoobenthos op twaalf raaien in de Waddenzee en de Eems-Dollard in 1998. NIOZ-Rapport 1999-2, NIOZ, Texel, p 1-53

Desprez M, Bachelet G, Beukema JJ, Ducrotoy JP, Essink K, Marchand J, Michaelis H, Robineau B, Wilson JG (1991) Dynamique des populations de Macoma balthica (L.) dans les estuaires du Nord-Ouest de l'Europe: première synthèse. In: Elliott M, Ducrotoy JP (eds) Estuaries and coasts: spatial and temporal intercomparisons. Olsen \& Olsen, Fredensborg, p 159-166

Dörjes J, Michaelis H, Rhode B (1986) Long-term studies of macrozoobenthos in intertidal and shallow subtidal habitats near the island of Norderney (East Frisian coast, Germany). Hydrobiologia 142:217-232

Ducrotoy JP, Rybarczyk H, Souprayen J, Bachelet G, Beukema JJ, Desprez M, Dörjes J, Essink K, Guillou J, Michaelis H, Sylvand B, Wilson JG, Elkaïm B, Ibanez F (1991) A comparison of the population dynamics of the cockle (Cerastoderma edule L.) in North-Western Europe. In: Elliott M, Ducrotoy JP (eds) Estuaries and coasts: spatial and temporal intercomparisons. Olsen \& Olsen, Fredensborg, p 173-184

Essink K (1978) The effects of pollution by organic waste on macrofauna in the eastern Dutch Wadden Sea. Neth Inst Sea Res Publ Ser 1:1-135

Essink K, Beukema JJ, Coosen J, Craeymeersch JA, Ducrotoy JP, Michaelis H, Robineau B (1991) Population dynamics of the bivalve mollusc Scrobicularia plana da Costa: comparisons in time and space. In: Elliott M, Ducrotoy JP (eds) Estuaries and coasts: spatial and temporal intercomparisons. Olsen \& Olsen, Fredensborg, p 167-172

Essink K, Beukema JJ, Madsen PB, Michaelis H, Vedel GR (1998) Long-term development of biomass of intertidal macrozoobenthos in different parts of the Wadden Sea. Governed by nutrient loads? Senckenb Marit 29:25-35

Fernandes TF, Huxham M, Piper SR (1999) Predator caging experiments: a test of the importance of scale. J Exp Mar Biol Ecol 241:137-154

Flach EC (1996) The influence of the cockle, Cerastoderma edule, on the macrozoobenthic community of tidal flats in the Wadden Sea. PSZN I: Mar Ecol 17:87-98

Fox CJ, Planque BP, Darby CD (2000) Synchrony in the recruitment time-series of plaice (Pleuronectes platessa L.) around the United Kingdom and the influence of sea temperature. J Sea Res 44:159-168

Franklin A, Pickett GD (1979) The assessment of commercial populations of the edible bivalve, Cardium edule. Rapp P-V Reun Cons Int Explor Mer 175:38-43

Hancock DA (1973) The relationship between stock and recruitment in exploited invertebrates. Rapp P-V Reun Cons Perm Int Explor Mer 164:113-131

Honkoop PJC, Beukema JJ (1997) Loss of body mass in winter in three intertidal bivalve species: an experimental and observational study of the interacting effects between water temperature, feeding time and feeding behaviour. J Exp Mar Biol Ecol 212:277-297

Honkoop PJC, Van der Meer J (1997) Reproductive output of Macoma balthica populations in relation to winter-temperature and intertidal-height mediated changes of body mass. Mar Ecol Prog Ser 149:155-162
Honkoop PJC, Van der Meer J, Beukema JJ, Kwast D (1998) Does temperature-influenced egg production predict the recruitment in the bivalve Macoma balthica? Mar Ecol Prog Ser 164:229-235

Hudson PJ, Cattadori IM (1999) The Moran effect: a cause of population synchrony. Trends Ecol Evol 14:1-2

Jensen KT (1992) Dynamics and growth of the cockle, Cerastoderma edule, on an intertidal mud-flat in the Danish Wadden Sea: effect of submersion time and density. Neth J Sea Res 28:335-345

Jensen KT (1993) Density-dependent growth in cockles (Cerastoderma edule): evidence from interannual comparisons. J Mar Biol Assoc UK 73:333-342

Jensen KT, Jensen JN (1985) The importance of some epibenthic predators on the density of juvenile benthic macrofauna in the Danish Wadden Sea. J Exp Mar Biol Ecol 89: $157-174$

Kamermans P (1993) Food limitation in cockles (Cerastoderma edule (L.)): influences of location on tidal flat and nearby presence of mussel beds. Neth J Sea Res 31:71-81

Kristensen I (1957) Differences in density and growth in a cockle population in the Dutch Wadden Sea. Arch Néerl Zool 12:351-453

Lammens JJ (1967) Growth and reproduction in a tidal flat population of Macoma balthica (L.). Neth J Sea Res 3: 315-382

McGrorty S, Goss-Custard JD (1993) Population dynamics of the mussel Mytilus edulis along environmental gradients: spatial variations in density-dependent mortalities. J Anim Ecol 62:415-427

McGrorty S, Clarke RT, Reading CJ, Goss-Custard JD (1990) Population dynamics of the mussel Mytilus edulis: density changes and regulation of the population in the Exe estuary, Devon. Mar Ecol Prog Ser 67:157-169

Menesguen A, Dreves L (1987) Sea-temperature anomalies and population dynamics variations: effects on growth and density of three bivalves. Mar Ecol Prog Ser 36:11-21

Möller P (1986) Physical factors and biological interactions regulating infauna in shallow boreal areas. Mar Ecol Prog Ser 30:33-47

Möller P, Rosenberg R (1983) Recruitment, abundance and production of Mya arenaria and Cardium edule in marine shallow waters, western Sweden. Ophelia 22:33-55

Ólafsson EB (1989) Contrasting influences of suspensionfeeding and deposit-feeding populations of Macoma balthica on infaunal recruitment. Mar Ecol Prog Ser 55: 171-179

Ólafsson EB, Peterson CH, Ambrose WG Jr (1994) Does recruitment limitation structure populations and communities of macro-invertebrates in marine soft sediments: the relative significance of pre- and post-settlement processes. Oceanogr Mar Biol Annu Rev 32:65-109

Peterson CH (1982) The importance of predation and intraand interspecific competition in the population biology of two infaunal suspension-feeding bivalves, Protothaca staminea and Chione umdatella. Ecol Monogr 52:437-475

Peterson CH, Black R (1987) Resource depletion by active suspension feeders on tidal flats: influence of local density and tidal elevation. Limnol Oceanogr 32:143-166

Pihl L, Rosenberg R (1982) Production, abundance, and biomass of mobile epibenthic marine fauna in shallow waters, western Sweden. J Exp Mar Biol Ecol 57:273-301

Reise K (1985) Tidal flat ecology. An experimental approach to species interactions. Springer Verlag, Berlin

Reise K (1987) Distribution and abundance of small and juvenile macrofauna on the tidal flats in the Frisian Wadden Sea. In: Tougaard S, Asbirk S (eds) Proc 5th Int Wadden 
Sea Symp, Nat Forest Nature Agency, Esbjerg, p 7-25

Richards MG, Huxham M, Bryant A (1999) Predation: a causal mechanism for variability in intertidal bivalve populations. J Exp Mar Biol Ecol 241:159-177

Smit CJ, Dankers N, Ens BJ, Meijboom A (1998) Birds, mussels, cockles and shellfish fishery in the Dutch Wadden Sea: how to deal with low food stocks for eiders and oystercatchers? Senckenb Marit 29:141-153

Thorson G (1950) Reproductive and larval ecology of marine bottom invertebrates. Biol Rev 25:1-45

Van der Hoeven PCT (1982) Observations of surface water temperature and salinity. State Office of Fishery Research (RIVO):1860-1981. Scientific Report WR 82-8. KNMI, De Bilt

Van der Meer J, Beukema JJ, Dekker R (2001) Long-term variability in secondary production of an intertidal bivalve

Editorial responsibility: Otto Kinne (Editor),

Oldendorf/Luhe, Germany population is primarily a matter of recruitment variability. J Anim Ecol 70: (in press)

Williams JG (1980) The influence of adults on the settlement of spat of the clam, Tapes japonica. J Mar Res 38:729-741

Wolff WJ (1973) The estuary as a habitat. Zool Verh (Leiden) 126:1-242

Young EF, Bigg GR, Grant A (1996) A statistical study of environmental influences on bivalve recruitment in the Wash, England. Mar Ecol Prog Ser 143:121-129

Ziegelmeier E (1978) Macrobenthos investigations in the eastern part of the German Bight from 1950 to 1974. Rapp P-V Reun Cons Int Explor Mer 172:432-444

Zwarts L (1991) Seasonal variation in body weight of the bivalves Macoma balthica, Scrobicularia plana, Mya arenaria and Cerastoderma edule in the Dutch Wadden Sea. Neth J Sea Res 28:231-245

Submitted: March 27, 2000; Accepted: July 27, 2000

Proofs received from author(s): February 2, 2001 